\title{
Fat Mass
}

National Cancer Institute

\section{Source}

National Cancer Institute. Fat Mass. NCI Thesaurus. Code C158256.

The weight of the body fat associated with either a particular body part or the whole body. 